\title{
Terminologia prawa rzeczowego w aspekcie tłumaczeniowym chińsko-polskim
}

\section{Terminology of Property Law in Chinese-Polish Translation}

\author{
Paulina Kozanecka \\ ZAKŁAD LEGILINGWISTYKI I JĘZYKÓW SPECJALISTYCZNYCH, \\ UNIWERSYTET IM. ADAMA MICKIEWICZA \\ AL. NIEPODLEGŁOŚCI 4, 61-874 POZNAŃ \\ skorupska@amu.edu.pl
}

\begin{abstract}
The aim of this paper is to analyse basic Chinese legal terminology related to property law and to translate the examined terms into Polish. The research material shall be the second book of Polish Civil Code (Ownership and Other Property Rights) published in 1964 and Chinese Property Rights Law published in 2007, as well as theoretical literature concerning property law. The author focuses mainly on the terms regarding property rights in general and also objects and subjects of particular property rights. Since in legal language specific phrases play a significant role, that is the reason for analyzing not only single words, but also full syntagmas - the terms in this paper are presented mainly inside phrases. Although Chinese and Polish property law institutions slightly differ, the terminology seems quite parallel. However, translator has to be careful to find an optimal equivalent, forasmuch literal translation commonly does not cover Polish statutory equivalent.
\end{abstract}

\begin{abstract}
Abstrakt
Celem artykułu jest analiza podstawowej chińskiej terminologii prawnej i prawniczej związanej z prawem rzeczowym przetłumaczenie badanych terminów na język polski. Materiał badawczy stanowiła księga druga polskiego Kodeksu cywilnego z 1964 r. („Własność i inne prawa rzeczowe") oraz chińska Ustawa o prawach rzeczowych z 2007 r., a także literatura prawnicza z zakresu prawa rzeczowego. Autorka skupia się głównie
\end{abstract}


na terminach dotyczących praw rzeczowych w ogólności oraz przedmiotach i podmiotach poszczególnych praw rzeczowych. $\mathrm{Z}$ uwagi na fakt, że $\mathrm{w}$ języku prawnym i prawniczym dużą rolę odgrywają określone zwroty, dlatego też analizie poddane zostały nie tylko pojedyncze słowa, ale i całe syntagmy - terminy przedstawione zostały głównie wewnątrz fraz. Choć instytucje chińskiego i polskiego prawa rzeczowego $\mathrm{w}$ pewnym stopniu się różnią, terminologia zdaje się być dość zbieżna. Jednakże tłumacz powinien zachować ostrożność w poszukiwaniu odpowiedniego ekwiwalentu, ponieważ dosłowne tłumaczenia nie zawsze pokrywają się $\mathrm{z}$ polskimi ekwiwalentami ustawowymi.

\section{Wykaz skrótów}

ch.u.pr.rz. - 中华人民共和国物权法 (Zhōnghuá Rénmín Gònghéguó wùquánfă) - ustawa o prawach rzeczowych Chińskiej Republiki Ludowej $\mathrm{z}$ dn. 16 marca $2007 \mathrm{r}$.

k.c. - ustawa z dnia 23 kwietnia 1964 r. - Kodeks cywilny (Dz.U. 1964 nr 16 poz. 93).

\section{Wstęp}

Rozwijające się nieustannie relacje polsko-chińskie, szczególnie na gruncie gospodarczym, wymagają ciągłej wymiany informacji. Znajomość prawa obu krajów powoli staje się warunkiem sine qua non wzajemnej współpracy polskich i chińskich przedsiębiorców (Oziewicz 2010). Dlatego też bardzo ważne jest położenie dużego nacisku na rozwój wiedzy o językach prawnych obu tych krajów, a także stopniowe rozwijanie kompetencji tłumaczy $\mathrm{w}$ zakresie polsko-chińskich i chińsko-polskich tłumaczeń prawniczych. Niniejszy artykuł jest zaledwie wstępem do porównawczych badań nad polskim i chińskim językiem prawnym, temat bowiem tak szeroki niewątpliwie wymaga ciągłego zgłębiania.

\subsection{Cel pracy}

Celem pracy jest analiza podstawowej chińskiej terminologii prawnej i prawniczej dotyczącej prawa rzeczowego i próba dokonania tłumaczenia badanych terminów na język polski. Prawo rzeczowe stanowi zaledwie fragment polskiego i chińskiego prawa, dlatego badanie to jest tak naprawdę tylko małym krokiem w kierunku pełnej analizy opisywanych lingua legis. Dogłębne zbadanie korpusów słownych polskiego i chińskiego prawa zaowocować może jednak efektywniejszym porównywaniem samego prawa, a co za tym idzie - szukaniem coraz lepszych rozwiązań legislacyjnych na przyszłość. 


\section{Paulina Skorupska: Terminologia prawa rzeczowego ...}

Zarówno w polskim, jak i chińskim współczesnym prawie cywilnym wiele instytucji wzorowane jest bądź zaczerpnięte m.in. $\mathrm{z}$ prawa rzymskiego oraz innych współczesnych prawach europejskich (Zhang 2004: 900). Fakt ten sprzyja badaniu tekstów źródłowych metodą analizy tekstów porównywalnych; w dużej mierze bowiem nie tylko regulacje prawne, ale i doktrynalna klasyfikacja instytucji prawnych są do siebie na tyle podobne, że możliwe jest efektywne ich porównywanie. Jednocześnie odrębne kultury prawne, a także sama odmienność kulturowa i historyczna tych państw powodują, że systemy prawne Polski i Chin, choć pozornie strukturalnie podobne, posiadają wiele, nierzadko zawoalowanych, różnic.

\subsection{Zakres pracy i materiał badawczy}

Jako przedmiot badań wybrane zostało polskie i chińskie prawo rzeczowe, a więc księga druga polskiej ustawy z dnia 23 kwietnia 1964 r. Kodeks cywilny (Dz.U. $1964 \mathrm{nr} 16$ poz. 93) - „Własność i inne prawa rzeczowe" - określanej dalej jako kodeks cywilny oraz chińska 中华人民共和国物权法 (Zhōnghuá Rénmín Gònghéguó wùquánfă) ustawa o prawach rzeczowych Chińskiej Republiki Ludowej z dn. 16 marca 2007 r., nazywana dalej (chińska) ustawą o prawach rzeczowych. Ponadto w trakcie badań analizowana była również polska i chińska literatura teoretyczna dotycząca prawa rzeczowego $\mathrm{w}$ celu zbadania terminów występujących nie tylko w samych ustawach, ale i funkcjonujących w doktrynie (z uwagi na fakt, że część terminów ustawowych jednego państwa ma swoje ekwiwalenty tylko $w$ literaturze teoretycznej drugiego państwa, a nie $\mathrm{w}$ samych tekstach prawnych, a więc część polskich terminów prawnych ma $\mathrm{w}$ Chinach ekwiwalenty będące nie częścią chińskiego języka prawnego, ale prawniczego - i vice versa).

Zarówno w Polsce, jak i w Chinach ustawodawca stworzył katalog zamknięty praw rzeczowych. W prawie polskim na prawa rzeczowe składają się instytucje uregulowane w Księdze drugiej Kodeksu cywilnego („Własność i inne prawa rzeczowe”):

1. własność (Tytuł I),

2. użytkowanie wieczyste (Tytuł II),

3. ograniczone prawa rzeczowe (Tytuł III).

W Chinach zaś są to wymienione w art. 2 ch.u.pr.rz.:

1. 所有权, suǒyǒuquán (własność) (Część II ch.u.pr.rz.),

2. 用益物权, yòngyì wù quán (prawa użytkowania) (Część III ch.u.pr.rz.),

3. 担保物权, dānbăo wù quán (prawa zabezpieczające) (Część IV ch.u.pr.rz.).

Ponadto w Polsce i w Chinach wyróżnia się posiadanie (Tytuł IV Księgi drugiej k.c.), chin. 占有, zhànyòu (Część V ch.u.pr.rz.).

$\mathrm{Z}$ uwagi na bardzo obszerny materiał, jaki stanowią poszczególne prawa rzeczowe, $\mathrm{w}$ artykule autorka skupiła się wyłącznie na terminach 
dotyczących praw rzeczowych w ogólności oraz ich przedmiotu i podmiotów.

\subsection{Metody badawcze}

Metodą stanowiącą alternatywę dla korzystania ze słowników specjalistycznych, które niejednokrotnie posiadają zbyt wąski zasób słownictwa bądź $\mathrm{w}$ praktyce nie istnieją, jak ma się to $\mathrm{w}$ przypadku terminologii prawniczej polsko-chińskiej i chińsko-polskiej, jest metoda analizy tekstów porównywalnych. Jest to metoda szczególnie użyteczna dla tłumaczenia prawniczego z uwagi na wielość powtarzających się tekstów w różnych językach, dotyczących tych samych dziedzin i skonstruowanych na podobnych zasadach. Teksty źródłowe winne być napisane w językach źródłowych oryginalnie, a także dotyczyć tych samych zagadnień lub prezentować ten sam typ (Grzybek 2013: 77-78). Porównanie tekstów źródłowych w różnych językach pozwala na odnalezienie ekwiwalentów dla terminów bądź fraz funkcjonujących w obu językach; możliwe jest zatem napotkanie terminu specyficznego tylko dla jednego języka, wówczas jest to zatem termin bezekwiwalentowy. Metoda ta niesie za sobą niebezpieczeństwo mylnego przypisania ekwiwalentu, jednak wnikliwe badanie instytucji prawnych i kontekstu pozwala na uzyskanie dużego stopnia pewności co do ekwiwalentności poszczególnych terminów.

Podczas tłumaczenia poszczególnych terminów prawniczych bardzo istotną jest kwestia ekwiwalencji. Odrzucenie dążenia do identyczności, jako stanu właściwie niemożliwego do osiągnięcia, skłania ku poszukiwaniu jak najdokładniejszych ekwiwalentów - z kluczowym zastrzeżeniem, że pełna ekwiwalencja mimo wszystko jest (zwłaszcza w przypadku tłumaczenia prawniczego) nieosiągalna (Nida, Taber 2010: 40-41).

W tłumaczeniu prawniczym warto zwrócić również uwagę na kwestię ekwiwalencji formalnej i dynamicznej. Mają one bezpośredni związek z funkcją normatywną i informacyjną tłumaczenia prawniczego.

Ekwiwalencja formalna polega na całkowitym zorientowaniu tłumaczenia na język źródłowy. Oznacza to, dla przykładu, brak tłumaczenia nazw instytucji, stosowanie nawiasów bądź kursywy w celu ewentualnego wyjaśniania terminów. W istocie jednak tekst powinien zachować całkowitą wierność oryginałowi (Nida 2012: 96-97). W praktyce skrajna ekwiwalencja formalna nie jest w pełni stosowana; faktycznie jednak pewne jej elementy wykorzystywane być moga $w$ tłumaczeniu normatywnym, w sytuacji, kiedy duże znaczenie ma np. rozróżnienie obcej i rodzimej instytucji prawnej.

Ekwiwalencji formalnej natomiast przeciwstawiona jest ekwiwalencja dynamiczna. Ten rodzaj polega na całkowitym zorientowaniu tłumaczenia na język docelowy, z czym wiąże się np. przełożenie nazw własnych na język docelowy, a w przypadku braku dokładnego ekwiwalentu zastosowanie innego bliskiego terminu, który niekoniecznie stanowi synonim. Ważną zasadą jest to, że ekwiwalencja dynamiczna zakłada 


\section{Paulina Skorupska: Terminologia prawa rzeczowego ...}

tłumaczenie $\mathrm{w}$ taki sposób, aby użytkownik języka docelowego odebrał tekst jak tekst pisany oryginalnie $\mathrm{w}$ jego języku (Nida 2012: 97-98). $\mathrm{W}$ tłumaczeniu prawniczym ekwiwalencja ta może znaleźć zastosowanie $\mathrm{w}$ przekładzie informacyjnym, który nie ma na celu rzetelnego oddania tekstu autentycznego, a jedynie przekazanie odbiorcy informacji na temat danego stanu prawnego. Niemniej jednak także i tej ekwiwalencji nie powinno się stosować skrajnie; mogłoby to bowiem doprowadzić do licznych zafałszowań. Faktem jest, że optymalnym będzie każdorazowe zastosowanie obu typów ekwiwalencji, w odpowiednich jednak proporcjach w zależności od danej sytuacji.

Możliwa jest jednak sytuacja, w której konkretny termin języka źródłowego nie będzie miał ekwiwalentu w języku docelowym. W takim momencie jednym z ważniejszych zadań tłumacza jako pośrednika między zamysłem autora tekstu a jego odbiorcą w języku docelowym jest zapewnienie ekwiwalencji dla terminu bezekwiwalentowego. Zadanie to jest tym trudniejsze, im odleglejsze są od siebie kultury obu języków. Tłumacz może bowiem natrafić na terminy określające byty, które w ogóle nie występują $w$ rzeczywistości języka docelowego. W języku prawnym terminy takie występują powszechnie - dotyczą najczęściej instytucji występujących $\mathrm{w}$ systemach prawnych tylko niektórych państw (bądź instytucji unikatowych). Obecnie wyróżnia się wiele technik zapewniania ekwiwalencji, które stosowane powinny być w uzależnieniu od typu odbiorcy tekstu docelowego (zob. Kłos, Matulewska, Nowak-Korcz 2007: 88-90).

\subsection{Terminologia prawna i prawnicza}

Charakterystycznym elementem odróżniającym język prawny (a także prawniczy) od języka etnicznego jest specyficzna terminologia. $\mathrm{W}$ przeciwieństwie do języka potocznego, nie występuje w języku prawnym tak szeroka synonimia. Wymóg precyzji semantycznej jest niezbędny, aby możliwe było szczegółowe sformułowanie reguł prawnych. Występowanie wielu terminów synonimicznych doprowadzałoby do dalekiej nieostrości pojęć, a tym samym pozwalałoby na niebezpieczną dowolność interpretacyjną. W języku tym występują również słowa celowo niedookreślone, mające umożliwić pozostawienie różnych dróg otrzymania wykładni. Powszechnie występuje także polisemia, wynikająca z przepisów bądź interpretacji praktyki prawniczej (Zedler 2010: 93). Niemniej jednak, choć pojedynczy termin cechować może wielość znaczeń, unika się stosowania różnych słów na określenie tego samego denotatu. Często zatem pojęcia występujące $\mathrm{w}$ języku potocznym jako bliskoznaczne w języku prawnym posiadać będą ściśle wskazane znaczenia (Hałas 1995: 23). Wiele terminów posiada również całkowicie odrębne znaczenie od swojego odpowiednika $\mathrm{w}$ języku potocznym (przykładem może być słowo „powód” - w języku potocznym oznacza przyczynę, w języku prawnym zaś dodatkowo osobę pozywającą). Tekst prawny czytany więc 
przez osobę niezaznajomioną $\mathrm{z}$ językiem prawnym może być albo niezrozumiały, albo błędnie zinterpretowany, $\mathrm{z}$ uwagi na rozbieżność znaczeniową zastosowanych terminów (Roszkowski 1999: 10-11).

Jednakże fakt, iż pewne terminy $w$ języku prawnym posiadają szczególne znaczenie, nie determinuje całkowitego wyeliminowania wieloznaczności. $Z$ tego też względu często niezbędne jest osadzenie konkretnej wypowiedzi w odpowiednim kontekście, aby rozwiane zostały wątpliwości co do znaczenia danego terminu. Dla przykładu, jakkolwiek przywołany termin powód posiada odrębne znaczenie w języku prawnym, to jednak prawodawca może użyć go i w znaczeniu języka potocznego (Malinowski 2012: 25-27).

Pomoc we właściwym odczytaniu treści tekstu prawnego stanowią definicje legalne, umieszczone najczęściej na początku tekstu. Ujednolicają one znaczenia pojęć, zwłaszcza, gdy użyte słowo posiada inne znaczenie lub kilka różnych znaczeń, bądź po prostu jest terminem nieostrym (Wronkowska 2005: 66-67). Definicje niezbędne są również w przypadku terminów, które w różnych gałęziach prawa niosą za sobą inne znaczenie (Zieliński M. 1999: 58). Często stosuje się również tzw. katalogi, a więc definiowanie terminów w sposób enumeratywny, wyliczając możliwe znaczenia danego pojęcia. Katalog może być zamknięty - wymienione wówczas znaczenia są wyłączne i niemożliwe jest dokooptowanie dodatkowych treści do definicji (ma ona wtedy charakter definicji równościowej nieklasycznej). Otwarty katalog zaś ma postać definicji cząstkowej - wymienione możliwości są jedynie przykładami i wszelkie podobne im elementy również przystają do definiendum (Wronkowska 2005: 67).

W przypadku chińskiego języka prawnego ważnym aspektem jest również odpowiednia kolejność słów. Ma to szczególne znaczenie z uwagi na fakt, iż w terminologii prawniczej wykształciło się wiele utartych zwrotów, które zapisane w odwrotnej kolejności niosą za sobą inne znaczenie - przykładem mogą tu być słowa: 比对 - „porównanie” i 对比 „kontrast” (Pan Qingyun 潘庆云 1991: 33).

\section{Prawo rzeczowe w Polsce i w Chinach}

Polski termin „prawo rzeczowe” rozumieć można w dwojaki sposób: pod względem przedmiotowym i podmiotowym. Ujęcie przedmiotowe określa prawo rzeczowe jako „zespół norm prawnych regulujących problematykę własności, użytkowania wieczystego, organiczonych praw rzeczowych oraz posiadania” (Dadańska 2012: 1) - w języku chińskim jest to termin 物权法, wùquánfă. Rozumienie podmiotowe natomiast to „normowane przepisami prawa rzeczowego formy prawne korzystania z rzeczy” (Doliwa 2010: 3) - chin. 物权, wùquán. Są to zatem majątkowe prawa cywilne, których przedmiotem jest rzecz (Gniewek 2012: 2). Prawa rzeczowe w rozumieniu podmiotowym rozpatrywane mogą być z trzech punktów widzenia: w relacji do rzeczy (przedmiotu praw rzeczowych), 
Paulina Skorupska: Terminologia prawa rzeczowego ...

w relacji do osoby (podmiotu praw rzeczowych) oraz pod względem ich przynależności (relacji między przedmiotem a podmiotem) (Yang Lixin 杨立新 2013: 39).

Uprawnienia wynikające $\mathrm{z}$ praw rzeczowych charakteryzują się wyłącznością (właściciel bowiem może się nimi cieszyć „z wyłączeniem innych osób”. Są to zatem prawa bezwzględne (erga omnes), kierowane do wszystkich osób trzecich - mają one obowiązek nienaruszania prawa właściciela. Tym też prawa rzeczowe różnią się od praw wynikających z zobowiązań, które skuteczne są tylko inter partes (Doliwa 2010: 4).

W tabeli przedstawiono najczęstsze syntagmy zawierające termin 物权, wùquán lub inne terminy z nim związane.

Tabela nr 1.: Prawo rzeczowe.

\begin{tabular}{lll}
\multicolumn{1}{c}{ JĘZYK CHINSKI } & \multicolumn{1}{c}{ PINYIN } & \multicolumn{1}{c}{ JĘZYK POLSKI } \\
物权 & wùquán & $\begin{array}{l}\text { prawo rzeczowe } \\
\text { (w sensie } \\
\text { podmiotowym) }\end{array}$ \\
\hline 物权法 & wùquánfă & $\begin{array}{l}\text { prawo rzeczowe } \\
\text { (w sensie } \\
\text { przedmiotowym) }\end{array}$ \\
\hline 财产权 & cáichănquán & prawo majątkowe \\
\hline 让与的财产权 & ràngyúde cáichănquán & $\begin{array}{l}\text { zbywalne prawo } \\
\text { majątkowe }\end{array}$ \\
\hline 国家的物权 & guójiā de wù quán & $\begin{array}{l}\text { prawa rzeczowe } \\
\text { państwowe }\end{array}$ \\
\hline 集体的物权 & jútǐ de wù quán & $\begin{array}{l}\text { prawa rzeczowe } \\
\text { kolektywu }\end{array}$ \\
\hline 私人的物权 & sìrén de wù quán & $\begin{array}{l}\text { prawa rzeczowe } \\
\text { prywatne }\end{array}$ \\
\hline 权利人的物权 & quánlì rén de wù quán & $\begin{array}{l}\text { prawa rależące do innych } \\
\text { podmiotów prawa }\end{array}$ \\
\hline 物权的种类 & wù quán de zhònglèi & $\begin{array}{l}\text { rodzaje praw } \\
\text { rzeczowych }\end{array}$ \\
\hline 物权的内容 & wù quán de nèiróng & \begin{tabular}{l} 
treść praw rzeczowych \\
\hline 不动产物权
\end{tabular} \\
\hline
\end{tabular}




\begin{tabular}{|c|c|c|}
\hline 动产物权 & dòngchăn wù quán & $\begin{array}{l}\text { prawa rzeczowe } \\
\text { dotyczące rzeczy } \\
\text { ruchomych }\end{array}$ \\
\hline 物权受法律保护 & $\begin{array}{l}\text { wù quán shòu fălü } \\
\text { băohù }\end{array}$ & $\begin{array}{l}\text { prawa rzeczowe } \\
\text { prawnie chronione }\end{array}$ \\
\hline 物权的行使 & wù quán de xíngshǐ & $\begin{array}{l}\text { wykonywanie praw } \\
\text { rzeczowych }\end{array}$ \\
\hline 物权的设立 & wù quán de shèlì & $\begin{array}{l}\text { ustanowienie praw } \\
\text { rzeczowych }\end{array}$ \\
\hline 物权的转让 & wù quán de zhuănràng & $\begin{array}{l}\text { przeniesienie praw } \\
\text { rzeczowych }\end{array}$ \\
\hline 物权的消灭 & wù quán de xiāomiè & $\begin{array}{l}\text { wygaśnięcie praw } \\
\text { rzeczowych }\end{array}$ \\
\hline 物权的合同 & wù quán de hétóng & $\begin{array}{l}\text { umowa } \\
\text { prawnorzeczowa }\end{array}$ \\
\hline 设立物权的合同 & $\begin{array}{l}\text { shèlì wù quán de } \\
\text { hétóng }\end{array}$ & $\begin{array}{l}\text { umowne ustanowienie } \\
\text { prawa rzeczowego }\end{array}$ \\
\hline 变更物权的合同 & $\begin{array}{l}\text { biàngēng wù quán de } \\
\text { hétóng }\end{array}$ & $\begin{array}{l}\text { umowna zmiana prawa } \\
\text { rzeczowego }\end{array}$ \\
\hline 转让物权的合同 & $\begin{array}{l}\text { zhuănràng wù quán de } \\
\text { hétóng }\end{array}$ & $\begin{array}{l}\text { umowne przeniesienie } \\
\text { prawa rzeczowego }\end{array}$ \\
\hline 消灭物权的合同 & $\begin{array}{l}\text { xiāomiè wù quán de } \\
\text { hétóng }\end{array}$ & $\begin{array}{l}\text { umowne wygaśnięcie } \\
\text { prawa rzeczowego }\end{array}$ \\
\hline 不动产物权的证明 & $\begin{array}{l}\text { bùdòngchăn wù quán } \\
\text { de zhèngmíng }\end{array}$ & $\begin{array}{l}\text { zaświadczenie } \\
\text { o prawach do } \\
\text { nieruchomości }\end{array}$ \\
\hline 物权登记 & wù quán dēngjì & $\begin{array}{l}\text { rejestracja praw } \\
\text { rzeczowych }\end{array}$ \\
\hline $\begin{array}{l}\text { 买卖房屋或者其他不动 } \\
\text { 产物权的协议 }\end{array}$ & $\begin{array}{l}\text { măimài fángwū } \\
\text { huòzhè qútā } \\
\text { bùdòngchàn wù quán } \\
\text { de xiéyi }\end{array}$ & $\begin{array}{l}\text { porozumienie w } \\
\text { sprawie sprzedaży } \\
\text { domu lub innej } \\
\text { nieruchomości }\end{array}$ \\
\hline 实现物权 & shíxiàn wù quán & $\begin{array}{l}\text { realizacja prawa } \\
\text { rzeczowego }\end{array}$ \\
\hline 物权效力 & wù quán xiàolì & $\begin{array}{l}\text { skuteczność prawa } \\
\text { rzeczowego }\end{array}$ \\
\hline $\begin{array}{l}\text { 物权自法律行为生效时 } \\
\text { 发生效力 }\end{array}$ & $\begin{array}{l}\text { wù quán zì fălùu } \\
\text { xíngwéi shèngxiào shí } \\
\text { fäshèng xiàolì }\end{array}$ & $\begin{array}{l}\text { prawo rzeczowe staje } \\
\text { sie skuteczne z chwila } \\
\text { dokonania czynności } \\
\text { prawnej }\end{array}$ \\
\hline
\end{tabular}


Paulina Skorupska: Terminologia prawa rzeczowego ...

\begin{tabular}{|c|c|c|}
\hline $\begin{array}{l}\text { 物权自该约定生效时发 } \\
\text { 生效力 }\end{array}$ & $\begin{array}{l}\text { wù quán zì gāi } \\
\text { yuēeìng shèngxiào shí } \\
\text { fāshēeng xiàoli }\end{array}$ & $\begin{array}{l}\text { prawo rzeczowe staje } \\
\text { się skuteczne z chwilą } \\
\text { zawarcia porozumienia }\end{array}$ \\
\hline 继承取得物权 & jìchéng qǔdé wù quán & $\begin{array}{l}\text { dziedziczne nabycie } \\
\text { praw rzeczowych }\end{array}$ \\
\hline 者受遗赠取得物权 & $\begin{array}{l}\text { zhě shòu yízèng qǔdé } \\
\text { wứ quân }\end{array}$ & $\begin{array}{l}\text { nabycie praw } \\
\text { rzeczowych w drodze } \\
\text { zapisu testamentowego }\end{array}$ \\
\hline 物权的保护 & wù quán de băohù & $\begin{array}{l}\text { ochrona praw } \\
\text { rzeczowych }\end{array}$ \\
\hline 物权受到侵害 & $\begin{array}{l}\text { wù quán shòudào } \\
\text { qinnhài }\end{array}$ & $\begin{array}{l}\text { prawa rzeczowe zostały } \\
\text { naruszone }\end{array}$ \\
\hline $\begin{array}{l}\text { 侵害物权 / } \\
\text { 妨害物权 }\end{array}$ & $\begin{array}{l}\text { qūnhài wù quán / } \\
\text { fánghâi wư quán }\end{array}$ & $\begin{array}{l}\text { naruszenie praw } \\
\text { rzeczowych }\end{array}$ \\
\hline
\end{tabular}

(Źródło terminów chińskich: ch.u.pr.rz).

Jak widać na przykładach, w języku chińskim termin 物权, wùquán („prawo rzeczowe” lub „prawa rzeczowe”) występuje w licznych kolokacjach, które większości mają swoje ekwiwalenty także w języku polskim.

Tłumaczenie na język polski terminów chińskich związanych z prawem rzeczowym w ogólności napotyka problemy, jednakże dotyczą one przede wszystkim odmienności na poziomie systemów prawnych (a nie instytucji). Niemniej jednak pewne wspólne podstawy polskiej i chińskiej regulacji (prawo europejskie, prawo rzymskie) sprawiają, że możliwe jest dobranie odpowiednich ekwiwalentów - na takim poziomie ogólności bowiem różnice systemowe nie są jeszcze aż tak wyraźnie zaznaczone.

\subsection{Przedmiot praw rzeczowych}

Przedmiotem praw rzeczowych (物权的客体, wùquánde kètì) jest, zarówno w Polsce, jak i w Chinach, rzecz (物, wù), będąca co do zasady przedmiotem materialnym, jednakże termin ten $\mathrm{w}$ prawie polskim i chińskim jest bardzo szeroko definiowany i klasyfikowany.

Zgodnie z art. 45 k.c., jako rzeczami są jedynie przedmioty materialne, $\mathrm{w}$ doktrynie jednak rozwinęla się szersza definicja tego terminu, określająca rzeczy jako (Wasilkowski [za:] Gniewek 2012: 4):

materialne części przyrody $\mathrm{w}$ stanie pierwotnym lub przetworzonym, na tyle wyodrębnione ( $w$ sposób naturalny lub sztuczny), że w stosunkach społeczno- 
gospodarczych mogą być traktowane jako dobra samoistne.

Rzeczą w prawie polskim nie mogą być ludzkie zwłoki, ani tkanki odłączone od ciała ludzkiego, jak również zwierzęta, choć przepisy o rzeczach są stosowane odpowiednio do zwierząt. Nie można terminem „rzecz” określić także zbioru rzeczy (w prawie polskim nie funkcjonuje bowiem pojęcie rzeczy zbiorowej) lub zbioru rzeczy i praw, jak np. gospodarstwo rolne (Dadańska 2012: 5). Niemniej jednak, ustawodawca dopuszcza, aby zbiory takie w określonych przypadkach stanowiły przedmiot praw rzeczowych, nie będąc jednocześnie rzeczą. Istnieją prawa rzeczowe, mające za przedmiot także inne majątkowe prawa podmiotowe. Dla przykładu, zgodnie z art. $265 \S 1$ k.c. „Przedmiotem użytkowania mogą być także prawa" (Gniewek, Machnikowski 2013: 451).

Podobnie jak w Polsce, w Chinach przedmiot praw rzeczowych stanowi 物, wù (rzecz). W chińskim systemie prawnym w stosunkach cywilnoprawnych 物, wù jest przedmiotem o najbardziej uniwersalnym i najszerszym znaczeniu. Termin ten jednak w języku prawnym nie znaczy w pełni tego samego, co w języku potocznym (Zhou Yang 周洋 2014: 8). 物, wù to przedmioty materialne, jednak w pewnych okolicznościach możliwe jest, aby przedmiotem praw rzeczowych stały się również prawa (mogą stać się np. przedmiotem zastawu) (Yin Tian 尹田, 2013: 34). Aby uznać przedmiot za 物, wù w rozumieniu chińskiego prawa cywilnego, powinien on cechować się następującymi atrybutami:

1. jest wyodrębniony i konkretnie wskazany;

2. służy zaspokajaniu potrzeb podmiotów prawa cywilnego (nie jest zatem rzeczą $\mathrm{w}$ rozumieniu prawa cywilnego obiekt nieużyteczny, jak popiół lub śnieg);

3. jest możliwy do rozporządzania przez podmiot prawa cywilnego (a więc nie jest rzeczą np. Słońce);

4. posiada niezależną wartość użytkową (nie jest rzeczą np. wagon kolejowy, ściana domu, noga stołu);

5. nie jest przedmiotem pochodzenia ludzkiego (np. organy wewnętrzne).

Ponadto, nieograniczone przedmioty materialne i niematerialne również mogą stać się 物, wù, np. energia elektryczna (Song Bingyong 宋炳庸, Guo Yukun 郭玉坤 2013: 95-96).

W prawie polskim istnieje dychotomiczny podział rzeczy na rzeczy ruchome i nieruchomości. Nie ma w polskim prawie definicji legalnej rzeczy ruchomej; doktrynalnie każdą rzecz niebędącą nieruchomością określa się jako rzecz ruchomą. Ustawodawca w art. 46 określa natomiast nieruchomości jako „części powierzchni ziemskiej stanowiące odrębny przedmiot własności (grunty), jak również budynki trwale $\mathrm{z}$ gruntem związane lub części takich budynków, jeżeli na mocy przepisów szczególnych stanowią odrębny od gruntu przedmiot własności”. Podział na rzeczy ruchome i nieruchome ma doniosłe znaczenie $\mathrm{w}$ polskim 


\section{Paulina Skorupska: Terminologia prawa rzeczowego ...}

systemie prawnym, wielokrotnie podlegają one bowiem różnym regulacjom prawnym, często wykluczającym się nawzajem, np. przedmiotem zastawu mogą być tylko rzeczy ruchome, podczas gdy hipoteka może być zastosowana wyłącznie w przypadku nieruchomości. Dla nieruchomości prowadzi się również księgi wieczyste, będące rodzajem rejestru właścicieli i wszelkich praw związanych z daną nieruchomością (Doliwa 2010: 8-9).

物, wù w prawie chińskim (art. 2 zd. 2 ch.u.pr.rz.) także dzielą się na 动产, dòngchăn (rzeczy ruchome) i 不动产, bùdòngchăn (nieruchomości) (art. 2 zd. 2 ch.u.pr.rz.) (Jones 1989: 91). Ciekawym jest fakt, iż w przeciwieństwie do terminu polskiego („rzecz ruchoma”), w chińskim określeniu 动产, dòngchăn nie występuje się znak 物, wù, ale znak 产, chăn stanowiący część słowa „mienie” (财产, cáichăn). W języku chińskim funkcjonuje co prawda słowo analogicznie zbudowane do polskiego terminu „rzecz ruchoma” - „动物”, oznacza ono jednak ,zwierzę”.

Podział rzeczy na ruchome i nieruchomości również ma istotne znaczenie dla stosowania prawa w Chinach, gdyż, podobnie jak w prawie polskim, wiele przepisów stosowanych jest wylącznie do 不动产, bùdòngchăn (nieruchomości) lub do 动产, dòngchăn (rzeczy ruchomych) (Wei Zhenying 魏振瀛 2013: 220). Prowadzony jest również 不动产登记, bùdòngchăn dēngjì (rejestr nieruchomości).

Nieruchomości dzielaa się $\mathrm{w}$ polskim systemie prawnym na trzy rodzaje: gruntowe, budynkowe i lokalowe (Dadańska 2012: 6). Nieruchomości gruntowe (inaczej: grunty), aby móc stać się przedmiotem praw rzeczowych, winny być wyodrębnione przedmiotowo (co oznacza określenie och granic), a także prawnie - powinien być określony ich właściciel $\mathrm{w}$ odpowiedniej księdze wieczystej. Warto $\mathrm{w}$ tym momencie wspomnieć, że w prawie polskim nie jest możliwa sytuacja, w której nieruchomość byłaby pozbawiona właściciela (Ziemianin, Dadańska 2012: 75). Zgodnie z funkcjonującą $\mathrm{w}$ polskim prawie zasadą superficies solo cedit, budynek wybudowany na gruncie stanowi część nieruchomości. Niemniej jednak istnieje możliwość wydzielenia budynku lub lokalu jako odrębnej nieruchomości - wówczas określa się je jako nieruchomość budynkową lub lokalową. W takim przypadku, nieruchomości budynkowe to trwale zwiazane z gruntem budynki, natomiast nieruchomości lokalowe to części takich budynków - zarówno jednak takie budynki, jak i lokale muszą na mocy przepisów szczególnych zostać wyodrębnione jako osobne nieruchomości, $\mathrm{w}$ przeciwnym bowiem razie będą stanowić po prostu część budynku (lokal) lub gruntu (budynek) (Gniewek 2012: 6).

Podział na rzeczy ruchome i nieruchomości nie jest jednak jedynym podziałem rzeczy; w prawie polskim i w prawie chińskim można rozróżnić także rzeczy oznaczone co do tożsamości (chin. 特定物, tèdìng wù) i rzeczy oznaczone co do gatunku (chin. 种类物, zhŏnglèi wù). Pierwszy typ dotyczy rzeczy, które można wskazać indywidualnie i nie mogą być one zastąpione; 
rzeczy oznaczone co do gatunku natomiast są określone rodzajowo (Song Bingyong 宋丙庸, Guo Yukun 郭玉坤 2013: 96). Nieruchomość w każdej sytuacji jest rzeczą oznaczoną co do tożsamości. W przypadku rzeczy ruchomych natomiast może się zdarzyć, że konkretna rzecz w jednej sytuacji zostanie określona jako oznaczona co do tożsamości (np. ten konkretny samochód), w innej zaś - co do gatunku (taki samochód, ale niekoniecznie ten wskazany) (Doliwa 2010: 9).

Ważnym rozróżnieniem jest także określenie części składowych rzeczy, rzeczy połączonych (chin. 添附物, tiānfùwù), przynależności (chin. 从物, cóngwù) oraz pożytków (chin. 杽息, $z \bar{x} x \bar{\imath}$ ).

Rzeczy utworzone na skutek złączenia innych rzeczy nazywane są rzeczami złożonymi (Doliwa 2010: 9). Ustawodawca wyróżnia przy tym rzeczy:

1. pomieszane (art. $193 \S 1$ k.c.),

2. połączone (art. $193 \S 1$ k.c),

3. wytworzone (przetworzone) (art. 192. § 2 k.c.).

Jeśli jednak jedna ze złączonych rzeczy ma znacznie większą wartość, niż inne $z$ tych rzeczy, stają się one wówczas jej częściami składowymi (Doliwa 2010:9). Jako część składową rzeczy ustawodawca określił w art. 47 k.c. „wszystko, co nie może być od niej odłączone bez uszkodzenia lub istotnej zmiany całości albo bez uszkodzenia lub istotnej zmiany przedmiotu odłączonego". Dodatkowo w kolejnym artykule określa części składowe gruntu, które stanowią rzeczy trwale związane z gruntem, w tym budynki oraz drzewa i inne rośliny. Część składowa nie może być przedmiotem praw rzeczowych, nie funkcjonuje bowiem samoistnie. Jeśli natomiast przedmiot zostanie połączony z rzeczą tymczasowo, nie uważa się go za część składową. Cześć składowa winna być połączona z rzeczą w sposób trwały, powinna istnieć między nimi także więź fizykalnoprzestrzenna (fizyczne i przestrzenne połączenie) i gospodarcza (wzajemna funkcjonalna relacja) (Dadańska 2012: 7). Dla przykładu, część składową samochodu stanowi jego koło. Za część składową nieruchomości uważa się również prawa związane z jej własnością (art. 50 k.c.).

W prawie chińskim także wyróżnia się 组成部分, zǔchéng bùfèn (części składowe) (Yin Tian 尹田 2013: 47), które również mogą tworzyć trzy rodzaje 添附物, tiānfùwù (rzeczy złożonych) (Song Bingyong 宋丙庸, Guo Yukun 郭玉坤 2013: 99):

1. 附合物, fùhéwù (rzeczy połączone), które mogą stanowić połączone rzeczy ruchome, rzecz ruchoma i nieruchomość bądź kilka nieruchomości - połączone tworzą nową rzecz (np. cegły i cement tworzą ścianę);

2. 混合物, hùnhéwù (rzeczy pomieszane), a więc rzeczy ruchome połączone w sposób trwały i tworzące zarazem nową rzecz (np. woda, winogrona i alkohol, tworzące ostatecznie wino); 
Paulina Skorupska: Terminologia prawa rzeczowego ...

3. 加工物, jiāgōngwù (rzeczy przetworzone/rzeczy wytworzone), jak np. drewno, z którego powstały panele.

W odróżnieniu od polskich części składowych i chińskich 组成部分, zǔchéng bùfèn oraz rzeczy złożonych i 添附物, tiānfùwù wskazać należy przynależności (chin. 从物, cóngwù). Są one odrębnymi rzeczami ruchomymi, jednak nie stanowią osobnego podmiotu praw rzeczowych, służą bowiem do korzystania z rzeczy głównej (chin. 主物, zhǔwù). Nie można jednak pomylić ich z częściami składowymi (Yin Tian 尹田 2013: 47). Mają one charakter pomocniczy, a także łączy je z rzeczą główną trwały i faktyczny związek gospodarczy. Ponadto zawsze występuje tożsamość podmiotowa właściciela przynależności i rzeczy głównej (Brzozowski, Kocot, Opalski 2012: 31). Przykładem przynależności może być smyczek do skrzypiec bądź wiosło do łodzi.

Ostatnim wymienionym przedmiotem są pożytki (chin. 爭息, zīxī) rzeczy (art. 53 k.c., art. 116 ch.u.pr.rz.) - cywilne (chin. 法定孚息, fădìng $z \bar{\imath} x \bar{\imath}$ ), nazywane też w Polsce dochodami; oraz naturalne (天然杽息, tiānrán zīxī), czyli płody rzeczy, a także odłączone od niej części składowe (jeśli są normalnym dochodem $\mathrm{z}$ rzeczy zgodnie $\mathrm{z}$ zasadami prawidłowej gospodarki) (Dadańska 2012: 10).

W tabeli poniżej znajdują się zestawione terminy związane z przedmiotem praw rzeczowych.

Tabela nr 2.: Przedmiot praw rzeczowych.

\begin{tabular}{lllll}
\multicolumn{1}{c}{ JĘZYK CHINSKI } & \multicolumn{1}{c}{ PINYIN } & \multicolumn{2}{c}{ JĘZYK POLSKI } \\
\hline 物 & wù & rzecz & \\
\hline 动产 & dong chan & rzecz ruchoma & \\
\hline 不动产 & bùdòngchăn & nieruchomość & & \\
\hline 特定物* & tèdìng wù & $\begin{array}{l}\text { rzeczy oznaczone } \\
\text { tożsamości }\end{array}$ & co do \\
\hline 种类物* & zhònglèi wù & $\begin{array}{l}\text { rzeczy oznaczone } \\
\text { gatunku co }\end{array}$ & do \\
\hline 添附物* & tiānfùwù & rzeczy złożone & \\
\hline 主物 & zhǔ wù & rzecz główna & \\
\hline 从物 & cóngwù & przynależność & \\
\hline 斈息 & zīxī & pożytki & \\
\hline 组成部分 & zǔchéng bùfèn & część składowa & & \\
\hline
\end{tabular}




\begin{tabular}{|c|c|c|}
\hline 附和物* & fùhéwù & rzeczy połączone \\
\hline 混合物* & hùnhéwù & rzeczy pomieszane \\
\hline 加工物* & jiāgōngwù & rzeczy przetworzone \\
\hline 财产 & cáichăn & mienie \\
\hline 物的归属 & wùde guīshǔ & władztwo nad rzeczą \\
\hline 返还原物的权利 & $\begin{array}{l}\text { fănhuán yuán wù } \\
\text { de quánlì }\end{array}$ & $\begin{array}{l}\text { prawo do zwrotu rzeczy } \\
\text { w stanie niepogorszonym }\end{array}$ \\
\hline 处分该物权 & chǔfèn gāi wù quán & rozporządzanie rzeczą \\
\hline $\begin{array}{l}\text { 不动产或者动产毁 } \\
\text { 损 }\end{array}$ & $\begin{array}{l}\text { bùdòngchăn huòzhě } \\
\text { dòngchăn huǐsǔn }\end{array}$ & $\begin{array}{l}\text { szkoda na nieruchomości } \\
\text { lub rzeczy ruchomej }\end{array}$ \\
\hline 不动产登记 & bùdòngchăn dēngjì & rejestr nieruchomości \\
\hline 动产交付 & dòngchăn jiāofù & wydanie rzeczy ruchomej \\
\hline
\end{tabular}

(Źródto terminów chińskich: ch.u.pr.rz.; terminy oznaczone gwiazdkq literatura prawnicza.)

Terminologia chińska dotycząca 物, $w u ̀$ (rzeczy) jako przedmiotu praw rzeczowych wyrażona jest przede wszystkim w rozdziale I ch.u.pr.rz., gdzie zdefiniowany został zarówno termin 物, wù, jak i dwa rodzaje 物, wù: 动产, dòngchăn (rzecz ruchoma) i 不动产, bùdòngchăn (nieruchomość). Teoretycznie, stanowiąc tak naprawdę podstawowy termin dla calego prawa rzeczowego, nie sprawia on trudności w tłumaczeniu. Jak opisano jednak powyżej, pewne różnice mogą pojawić się na dużo bardziej szczegółowym poziomie analizy zakresu znaczenia tego terminu i terminu „rzecz”. Choć więc kolokacje z tymi terminami w języku chińskim i polskim mogą być podobne ze względu na strukturę, to samo ich znaczenie niekoniecznie.

Istotnym jest rozróżnienie terminów „rzecz” (物, wù), „mienie” (财产, cáichăn) i „własność” (所有权, suǒyǒuquán), które - przeciwnie niż $\mathrm{w}$ języku prawnym - w Polsce potocznie stanowią wyrazy bliskoznaczne. Dodatkową znaczącą różnicą jest fakt, że polski termin „rzecz ruchoma” w Chinach określana jest dosłownie „mieniem ruchomym” (动产, dòngchăn). Problem ten $\mathrm{z}$ pozoru nie powstawał przy terminie „nieruchomość” (不动产, bùdòngchăn), które w Polsce nie ma związku ze słowem „rzecz”, niemniej jednak i tak różni się od pojęcia chińskiego, oznaczającego literalnie „mienie nieruchome”.

Warto zwrócić także uwagę na klasyfikację 物, wù, która choć w Chinach występuje częściowo tylko w języku prawniczym, a nie 
prawnym, ma istotne znaczenie dla określenia znaczenia tego terminu (np. czy terminem 物, wù określić można kilka rzeczy w określony sposób złączonych ze sobą).

物, wù pojawia się także w licznych terminach na przestrzeni całej ustawy, w większości przypadków jednak nie występuje w znaczeniu „rzeczy” i stanowi jedynie element słowotwórczy tych terminów.

\subsection{Podmioty praw rzeczowych}

Nazwy podmiotów poszczególnych praw rzeczowych zarówno w Polsce, jak i w Chinach w znacznej mierze wynikają $\mathrm{z}$ nazw odpowiadających im praw rzeczowych (np. własność - właściciel; 所有权, suǒyǒuquán - 所有权人, suǒyǒuquánrén). Nie można jednak stwierdzić całkiem stałej reguły dotyczącej tworzenia terminów określających te podmioty. Choć pewne zasady są i w niektórych przypadkach zdają się być w dużym stopniu powtarzalne obserwowalne (jak widać będzie na przykładach - nieraz w dużej mierze), to jednak istnieją od nich pewne odstępstwa.

Fakt związania nazwy podmiotu z wykonywanym przez niego prawem skutkuje także problemem braku ekwiwalentów w języku prawnym dla nazw podmiotów tych praw, które w drugim systemie prawnym nie występują. Kwestia ta ma znaczenie również w przypadku praw podobnych, a jednak w znacznym stopniu różniących się od siebie. Niemniej jednak, choć na szczegółowym poziomie odnaleźć można liczne różnice, możliwe jest odwołanie się do ogólnej klasyfikacji praw rzeczowych, która w Polsce i w Chinach jest zbliżona.

Z tego też względu porównanie wymagało wnikliwej analizy tekstów porównywalnych $\mathrm{w}$ celu odnalezienia właściwych ekwiwalentów dla terminów oznaczających podmioty praw rzeczowych, które przedstawione zostały w tabeli poniżej.

Tabela nr 3.: Podmioty praw rzeczowych.

\begin{tabular}{lll}
\multicolumn{1}{c}{ JĘZYK CHIŃSKI } & \multicolumn{1}{c}{ PINYIN } & \multicolumn{1}{c}{ JĘZYK POLSKI } \\
$\begin{array}{l}\text { 所有权人 / } \\
\text { 业主 }\end{array}$ & $\begin{array}{l}\text { suǒyǒuquánrén / } \\
\text { yèzhǔ }\end{array}$ & właściciel \\
\hline 用益物权人 & yòngyì wù quán rén & użytkownik \\
\hline & tǔdì & chéngbāo \\
土地承包经营权人 & $\begin{array}{l}\text { osoba uprawniona do } \\
\text { umownego zarządzania } \\
\text { gruntem }\end{array}$ \\
\hline
\end{tabular}




\begin{tabular}{|c|c|c|}
\hline 建设用地使用权人 & $\begin{array}{l}\text { jiànshè yòngdì } \\
\text { shǐyòng quán rén }\end{array}$ & $\begin{array}{l}\text { osoba uprawniona do } \\
\text { użytkowania gruntu } \\
\text { w celach budowlanych }\end{array}$ \\
\hline 宅基地使用权人 & $\begin{array}{l}\text { zháijīìi } \quad \text { shìyòng } \\
\text { quán rén }\end{array}$ & $\begin{array}{l}\text { osoba uprawniona do } \\
\text { użytkowania gruntu } \\
\text { w celach mieszkaniowych }\end{array}$ \\
\hline 地役权人 & dì yì quán rén & $\begin{array}{l}\text { właściciel nieruchomości } \\
\text { władnącej }\end{array}$ \\
\hline 供役地权利人 & gōng yì dì quánlì rén & $\begin{array}{l}\text { właściciel nieruchomości } \\
\text { obciążonej }\end{array}$ \\
\hline 当事人 & dāngshìrén & strony \\
\hline 第三人 & dì sān rén & osoba trzecia \\
\hline 权利人 & quánlì rén & osoba uprawniona \\
\hline 无处分权人 & wú chǔfèn quán rén & $\begin{array}{l}\text { osoba nieuprawniona do } \\
\text { rozporządzania }\end{array}$ \\
\hline 抵押权人 & dǐyāquánrén & wierzyciel hipoteczny \\
\hline 抵押人 & dìyārén & dłużnik hipoteczny \\
\hline 债权人 & zhàiquánrén & wierzyciel \\
\hline 债务人 & zhàiwùrén & dłużnik \\
\hline 质权人 & zhìquánrén & zastawnik \\
\hline 出质人 & chūzhìrén & zastawca \\
\hline
\end{tabular}

(Źródlo terminów chińskich: ch.u.pr.rz.)

W języku prawnym nazwa, jaką oznacza się podmioty określonych praw, jest niezwykle ważna, zawsze bowiem niesie za sobą szereg uprawnień i obowiązków. Na postawie powyższych przykładów zauważyć można, że język chiński stosuje dość prostą zasadę tworzenia nazw takich podmiotów: $\mathrm{w}$ wielu przypadkach jest to po prostu nazwa instytucji z dodanym znakiem ”人” (rén) - „człowiek”, np. „建设用地使用权”(jiànshè yòngdì shìyòng quán) - „prawo użytkowania gruntu w celach budowlanych” $\mathrm{i}$, 建设用地使用权人” (jiànshè yòngdì shìòng quán rén) „osoba uprawniona do użytkowania gruntu w celach budowlanych”. 


\section{Paulina Skorupska: Terminologia prawa rzeczowego ...}

W przypadku „par” osób mających przeciwstawne uprawnienia, między nazwą instytucji a słowem ,人” dodany zostaje zazwyczaj znak ,权” (quán) - „uprawnienie” dla osoby uprawnionej i „务”(wù) - „interes” dla osoby obciążonej, np. „债权人” (zhàiquánrén) - „wierzyciel” i ”债务人” (zhàiwùrén) - „dłużnik”.

Inny problem stwarzać może zupełnie odmienna konstrukcja nazwy podmiotu. Przykładowo ekwiwalentem terminu 地役权人, dì yì quán rén, (który w literalnym tłumaczeniu oznacza „osobę uprawnioną do służebności”) w języku polskim jest ustawowy termin „właściciel nieruchomości władnącej”.

W polskim języku prawnym także większość terminów stanowi derywaty nazw instytucji, jednak ich znaczenie jest umowne, np. „zastaw” „zastawca” i „zastawnik”; struktura słowa nie zawsze więc określa jednoznacznie, kto jest osobą uprawnioną, a kto - obciążoną. Nie można również stosować tu analogii: np. w przypadku terminu „najem” jedną ze stron jest „najemca” (utworzony analogicznie do „zastawcy”), jednak drugiej strony nie określa się odpowiednio do „zastawnika” „najemnikiem” (które to słowo ma całkiem odrębne znaczenie), a „wynajmującym”.

Jednakże oczywistym zdaje się fakt, że w odpowiednim przetłumaczeniu nazwy podmiotu duże (być może największe) znaczenie ma właściwe przetłumaczenie nazwy posiadanego przez niego prawa. Jak już wspomniano, terminy dotyczące podmiotów praw są derywowane z terminów określających poszczególne prawa (choć zasady ich tworzenia w dużej mierze zależą od typu morfologicznego danego języka, które w języku polskim i chińskim są niemalże skrajnie różne). Ta oczywista zależność może zatem stanowić dużą pomoc w utworzeniu właściwego ekwiwalentu dla terminu bezekwiwalentowego określającego pomiot prawa rzeczowego.

\section{Wnioski translacyjne}

Pomimo znacznej różnicy morfologicznej języków, a także dzielących je odmiennych kultur prawnych, możliwe było skuteczne zrealizowanie celu pracy, jakim było zbadanie i przetłumaczenie podstawowych chińskich terminów dotyczących prawa rzeczowego na język polski.

Podczas tłumaczenia terminów niewątpliwie pomocna okazała się metoda analizy tekstów porównywalnych. Chińska ustawa o prawach rzeczowych i księga druga polskiego kodeksu cywilnego charakteryzują się podobną strukturą i kolejnością opisywanych praw. Odnalezienie wzajemnych odpowiedników poszczególnych instytucji prawa rzeczowego umożliwiało także identyfikację konkretnych wyrazów czy fraz. Niejednokrotnie bowiem przetłumaczone dosłownie terminy nie stanowiły pojęć polskiego języka prawnego; porównanie tekstów autentycznych pozwalało zatem na odnalezienie właściwych ekwiwalentów. 
Tłumaczenie nie obyło się jednak bez głębszej analizy funkcjonowania instytucji prawnych. W wielu przypadkach dopiero zbadanie istoty danej instytucji pozwalało na zaklasyfikowanie poszczególnych związanych $\mathrm{z}$ nią terminów jako ekwiwalentów pojęć polskich. W niektórych przypadkach analiza pomogła uniknąć błędu, który mógłby wynikać z mylącego podobieństwa pewnych wyrazów.

Podczas tłumaczenia pewną trudność stanowiły także różnice dzielące język polski i język chiński w ogólności. Mierząc się z odmiennymi regułami budowania terminów należało mieć na uwadze fakt, by nie zastosować kalki, która mogłaby nieść za sobą inne znaczenie, bądź aby nie pominąć elementu frazy, który np. w języku źródłowym nie występował.

Ważnym jest fakt, że mowa tu o tłumaczeniu połączonym z badaniem instytucji prawnych, gdyż oba te procesy zachodzić musiały jednocześnie. Niemożliwym było bowiem przestudiowanie treści ustawy bez znajomości słownictwa, podobnie jak bezowocne byłoby tłumaczenie bez wiedzy o tym, co dokładnie oznacza tłumaczony termin. Istotną pomoc stanowiła literatura przedmiotu; w wielu pozycjach możliwe było odnalezienie wyjaśnień terminów, bądź dokładnych opisów funkcjonowania instytucji prawnych, co z kolei umożliwiało odnalezienie ekwiwalentów w tekstach autentycznych.

Chińska terminologia języka prawnego dotyczącego praw rzeczowych nie odbiega znacząco od terminologii polskiej, choć istnieją $\mathrm{w}$ nich pewne zasadnicze różnice mogące sprawiać tłumaczom problemy. Większość terminów posiada jednak swoje bliższe lub dalsze ekwiwalenty. $\mathrm{W}$ przypadku instytucji funkcjonujących w Polsce, które nie istnieją w Chinach, niezbędne jest zastosowanie ekwiwalentów opisowych. $\mathrm{W}$ tłumaczeniu chińsko-polskim dotyczyło to nielicznych terminów, w większości bowiem możliwe było użycie ekwiwalentu funkcjonalnego.

Tak krótka analiza chińskiej terminologii nie wyczerpuje jednak tematu. Materiał badawczy jest bowiem tak obszerny, że każda z instytucji prawa rzeczowego stanowić może przedmiot osobnej monografii. Dokonane badania wskazują jednak, że możliwe jest skuteczne analizowanie i porównywanie polskiego i chińskiego języka prawnego. W Polsce studia nad chińskim językiem prawnym to coraz szybciej rozwijająca się dziedzina. Nie powstał jak dotąd zbiorczy polsko-chiński czy chińsko-polski słownik terminologii prawniczej. Liczne badania i publikacje z tym związane świadczą jednak o dużej szansie na powstanie takiej pozycji w przyszłości, co stanowiłoby znaczący krok w kierunku badania nie tylko chińskiego języka prawnego, ale i chińskiego systemu prawa w Polsce. 


\section{Paulina Skorupska: Terminologia prawa rzeczowego ...}

\section{Bibliografia}

Brzozowski A., Kocot W. J., Opalski W. 2012. Prawo rzeczowe: Zarys wykładu. Warszawa: Wydawnictwo LexisNexis.

Dadańska K. 2012. Prawo rzeczowe. Warszawa: Wydawnictwo C.H. Beck.

Doliwa A. 2010. Prawo rzeczowe. Warszawa: Wydawnictwo C.H. Beck.

Gniewek E. 2012. Prawo rzeczowe. Warszawa: Wydawnictwo C.H. Beck.

Gniewek E., Machnikowski P. (Ed.) 2013. Kodeks cywilny. Komentarz. Warszawa: Wydawnictwo C. H. Beck.

Grzybek J. 2013. Alternatywne metody rozwiązywania sporów w przekładzie chińsko-polskim $i$ polsko-chińskim. Poznań: Wydawnictwo Naukowe CONTACT.

Hałas B. 1995. Terminologia języka prawnego. Zielona Góra: WSP TK.

Jones W. C. (Ed.) 1989. Basic Principles of Civil Law in China. New York: M. E. Sharpe, Inc.

Kłos P., Matulewska A., Nowak-Korcz P. 2007. Problemy przekładu specjalistycznego na przykładzie tekstów z dziedziny prawa, biologï, biotechnologii i medycyny. w: „Investigationes Linguisticae”, vol. XV, pp. 8099.

Malinowski A. 2012. Polski tekst prawny: Opracowanie treściowe i redakcyjne. Wybrane wskazania logiczno-językowe. Warszawa Wydawnictwo Prawnicze LexisNexis.

Nida E. (2012). Formal Equivalence and Dynamic Equivalence. w: Zhang Sijie (张思洁) (Ed.) 法律英语翻译读本. 南京: 南京大学出版社, pp. 86-102.

Nida E., Taber Ch. 1969. The Nature of Translating. w: Liao Qiyi (廖七一) (Ed.) 2010. Contemporary Translation Studies in the West: A Reader. Beijing: Foreign Language Teaching and Research Press, pp. 39-58.

Oziewicz E. 2010. 60 lat polsko-chińskich stosunków gospodarczych. w: Włodarski J., Zeidler K., Burdelski M. (Ed.). Chiny w oczach Polaków. Księga jubileuszowa $z$ okazji 6o-lecia nawiązania stosunków dyplomatycznych między Polska a Chińska Republika Ludowa. Gdańsk: Wydawnictwo Uniwersytetu Gdańskiego, pp. 573-583.

Pan Qingyun (潘庆云) 1991. 法律语体探索. 昆明: 云南人民出版社.

Roszkowski S. 1999. The Language of Law as Sublanguage. W: Tomaszczyk J. (Ed.) Aspects of Legal Language and Legal Translation. Łódź: Wydawnictwo Uniwersytetu Łódzkiego, pp. 7-16.

Song Bingyong (宋炳庸), Guo Yukun (郭玉坤) 2013. 实用民法总则. 北京: 法律出版社.

Wei Zhenying (魏振瀛) (Ed.) 2013. 民法. 北京: 北京大学出版社.

Wronkowska S. 2005. Podstawowe pojęcia prawa i prawoznawstwa. Poznań: Wydawnictwo Ars boni et aequi.

Yang Lixin (杨立新) 2013. 物权法. 北京: 法律出版社.

Yin Tian (尹田) 2013. 物权法. 北京: 北京大学出版社.

Zedler F. 2010. Wybrane zagadnienia z zakresu prawa ipostępowania cywilnego $w$ aspekcie translatologicznym zjęzyka polskiego na angielski. W: „Legilingwistyka Porównawcza”, vol. 3. Poznań: Uniwersytet im. Adama Mickiewicza, pp. 93-114.

Zhou Yang (周洋) (Ed.) 2014. 物权: 常见法律问题及纠纷解决法条速查与文书范本. 北京: 法律出版社. 
Investigationes Linguisticae, vol. XXXI

Zhang L. 2004. The Codification of Civil Law in China: History, Current Situation and Prospective. w: Studium Iuris, vol.7/8, 2004, pp. 896-908. 